Jurnal Ilmu Keperawatan : Journal of Nursing Science 2020. Vol. 8, No. 1, 15-21

www.jik.ub.ac.id

Doi 10.21776/ub.jik.2020.008.01.3

P-ISSN: 2088-6012 E-ISSN: 2598-8492

Case study

\title{
NURSING CARE OF PATIENT WITH SEPSIS DUE TO BLAST INJURY
}

Efris Kartika Sari ${ }^{1}$, Nisofa $^{2}$, Rendi Yoga Saputra ${ }^{1}$, Masriami $^{1}$, Mohammad Khoirudin ${ }^{1}$, Richardus MGP Lahamukang ${ }^{1}$, Klara Yunita Inuq Thomas ${ }^{1}$

Afiliasi

1. School of Nursing, Faculty of Medicine, Universitas Brawijaya

2. dr. Saiful Anwar General Hospital, Malang

Dikirim 28 Oktober 2019

Direvisi 30 Januari 2020

Diterima 06 Februari 2020

Dipublikasikan 30 Juni 2020

*Korespondensi

Email :

efriskartika@ub.ac.id

\begin{abstract}
ABSTRAK
Cedera ledakan merupakan cedera yang diakibatkan oleh mekanisme barotrauma (melibatkan tekanan yang berlebihan) sehingga dapat menyebabkan trauma organ tubuh. Kondisi trauma organ dan kerusakan permukaan tubuh yang luas menyebabkan pasien dengan cedera ledakan rentan mengalami sepsis. Seorang lakilaki dirawat di rumah sakit akibat cedera ledakan. Pasien diketahui mengalami luka bakar derajat III seluas 18\% pada area abdomen dan paha kanan, serta trauma femur kanan. Pasien menjalani tindakan pembedahan berupa disartikulasi panggul kanan dan debridement luka pada area abdomen. Pasca pembedahan, pasien mengalami penurunan kesadaran dan gagal napas sehingga dirawat di ruang rawat intensif. Hasil pengkajian menunjukkan pasien mengalami sepsis. Masalah keperawatan pada pasien tersebut yaitu ketidakefektifan bersihan jalan napas, hambatan ventilasi spontan, risiko syok, dan kerusakan integritas jaringan. Perawat melakukan asuhan keperawatan untuk mempertahankan kepatenan jalan nafas, memberikan ventilasi yang adekuat, mempertahankan kestabilan hemodinamik, serta mengoptimalkan proses penyembuhan luka pada pasien.
\end{abstract}

Kata kunci : cedera ledakan, sepsis, asuhan keperawatan

\begin{abstract}
Blast injury is an injury due to the mechanism of barotrauma (involving excessive pressure) which results in organ trauma. Trauma and extensive injury can progress to sepsis condition to the patient. A man is hospitalized due to blast injury. The patient suffered a third-degree burn involving 18\% total body surface area located in the abdomen and right thigh, and right femoral trauma. The patient has right hip disarticulation and abdominal wound debridement surgery. After surgery, the patient has decreased consciousness and respiratory failure so that he was treated in the intensive care unit. The nursing assessment identified that patient has sepsis conditions. Nursing problems of the patient are ineffective airway clearance, impaired spontaneous ventilation, the risk for shock, and impaired tissue integrity. The nurse performs nursing care to maintain airway patency, provide adequate ventilation, maintain hemodynamic stability, and optimize the wound healing process of the patient.
\end{abstract}

Keyword : blast injury, sepsis, nursing care

Sitasi jurnal :

Sari, Efris Kartika, et al. 2020. Nursing Care of Patient with Sepsis due to Blast Injury. Jurnal Ilmu Keperawatan 8(1): 15-21. Doi 10.21776/ub.jik.2020.008.01.3 


\section{PENDAHULUAN}

Cedera ledakan merupakan kasus yang jarang terjadi, namun bersifat mengancam nyawa (Samra, Pawar, \& Kaur, 2014). Cedera ledakan dapat disebabkan oleh ledakan bom, kecelakaan kerja yang melibatkan tekanan yang tinggi, ledakan gas LPG pada pemakaian rumah tangga, serta kejadian lain yang terkait kecelakaan ataupun kasus kriminal. Berdasarkan data Badan Perlindungan Konsumen Nasional (BPKN) Republik Indonesia, sejak tahun 2007 sampai Juni 2010 terjadi 95 kasus ledakan tabung gas dengan jumlah korban luka-luka sebanyak 135 orang dan korban meninggal sebanyak 22 orang (BPKN, 2010). Selain itu, kasus cedera ledakan akibat tindakan kriminal mulai mendapat perhatian secara luas di Indonesia sejak kasus bom Bali I pada tahun 2002 yang menyebabkan korban 300 orang luka-luka dan 202 orang tewas (Syafii, 2017).

Cedera ledakan merupakan cedera yang diakibatkan oleh mekanisme barotrauma (melibatkan tekanan yang berlebihan). Tekanan tersebut mempengaruhi laju bahan peledak yang memiliki efek merusak apabila mengenai permukaan tubuh. Kerusakan yang ditimbulkan mekanisme barotrauma tergantung pada tekanan puncak, durasi, media ledakan (udara terbuka, ruang terbatas, atau air), dan jarak ledakan. Organ tubuh yang berisi udara dan cairan sangat rentan mengalami kerusakan akibat efek tekanan berlebihan (Jorolemon \& Krywko, 2019).

Paparan ledakan pada tubuh dapat mengakibatkan efek primer berupa kerusakan kulit, trauma paru, ruptur membran timpani, perdarahan perut, perforasi bola mata, dan cedera otak. Efek sekunder cedera ledakan ditimbulkan oleh bahan-bahan pecahan bom yang dapat mengakibatkan penetrasi pada mata, cedera otak, dan berbagai masalah medis lainnya. Efek tersier cedera ledakan ditimbulkan oleh hempasan angin ledakan pada seseorang yang dapat menyebabkan fraktur, amputasi traumatis, cedera otak, dan sejumlah masalah medis lainnya. Efek kuarter cedera ledakan mengacu pada semua cedera, penyakit, atau penyakit terkait ledakan yang bukan disebabkan oleh mekanisme primer, sekunder, atau tersier. Efek kuarter diklasifikasikan atas dasar serangkaian cidera dimana sudah terjadi hiperinflamasi pada sistem tubuh pasien (Jorolemon \& Krywko, 2019).
Kondisi trauma organ dan kerusakan permukaan tubuh yang luas menyebabkan pasien dengan cedera ledakan rentan mengalami sepsis. Sepsis merupakan kondisi disfungsi organ yang mengancam jiwa yang disebabkan oleh disregulasi respon tubuh terhadap infeksi (Camm et al., 2018; Finkelsztein et al., 2017). Sepsis terjadi ketika pasien terinfeksi dan respon inflamasi tubuh tidak adekuat. Akibatnya, terjadi respon inflamasi yang menetap melalui aktivasi mediator inflamasi secara terus menerus, hipoksia seluler, kerusakan jaringan, syok, kegagalan organ, dan berpotensi mengakibatkan kematian (Bennett, Dolin, \& Blaser, 2015).

Pedoman sepsis yang terbaru oleh The Sepsis Definition Task Force yaitu Sepsis-3, menekankan kebutuhan akan identifikasi dini dan penatalaksanaan cepat selama proses sepsis berlangsung, sehingga dapat menurunkan morbiditas dan mortalitas pasien sepsis (Finkelsztein et al., 2017). Perawat perlu berperan aktif dalam upaya identifikasi dini dan penatalaksanaan pasien sepsis. Artikel ini bertujuan untuk mengetahui asuhan keperawatan pada pasien dengan cedera ledakan yang mengalami sepsis.

\section{LAPORAN KASUS}

Seorang laki-laki (65 tahun) dirawat di rumah sakit akibat cedera ledakan. Pasien bekerja sebagai petani. Pasien mengalami cedera ledakan akibat dilempari bom (diduga memiliki daya ledak rendahsedang) oleh dua orang tak dikenal saat berangkat ke sawah. Pasien langsung dibawa ke rumah sakit untuk mendapatkan pengobatan.

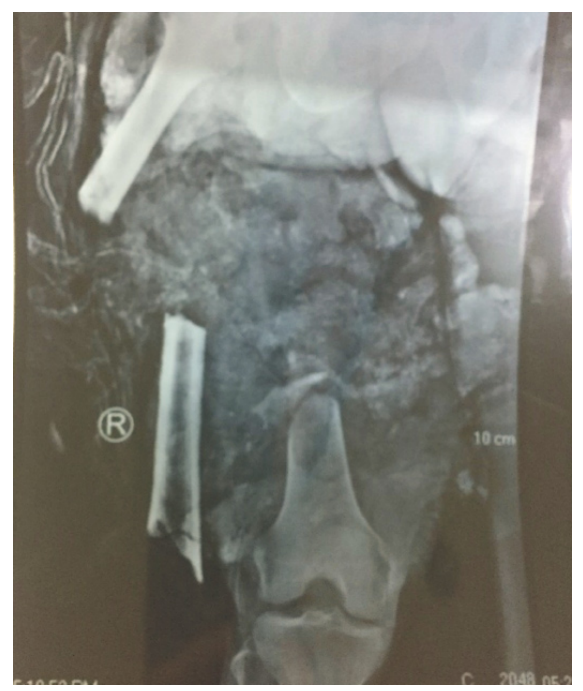

Gambar 1. Foto Rontgen Femur Kanan 
Pasien diketahui mengalami luka bakar derajat III seluas $18 \%$ pada area abdomen dan paha kanan, serta trauma femur kanan. Selanjutnya dilakukan tindakan pembedahan berupa disartikulasi panggul kanan dan debridement luka pada area abdomen. Pasca pembedahan, klien mengalami penurunan kesadaran dan gagal napas sehingga dirawat di ruang rawat intensif.

Hasil pengkajian fisik pada pasien sebagai berikut: Breath (B1): pada mulut pasien terpasang endotracheal tube (ETT) yang terhubung pada ventilator mekanik dengan pengaturan mode pressure control yaitu: PC SIMV, PEEP: 6, frekuensi: $22 \mathrm{x} /$ menit, TV(i) : $263 \mathrm{ml}$, MV (i): 7.6 lpm, P Support: $15 \mathrm{mmH} 20$, P inspirasi / P control: 24 mmH20, Trigger 2 lpm, FiO2: 100\%. Pasien batuk, pengembangan dada simetris, produksi sputum purulen (konsistensi kental, berwarna kuning pekat), terdengar ronkhi pada lobus paru kiri dan kanan atas, frekuensi pernafasan 27 - 30 x/menit. Blood (B2): pasien menggunakan central venous catheter (CVC) pada subclavia kanan sebagai akses vaskular, tekanan darah 115-125/57-77 mmHg, nadi 120-135 x/ menit. Pasien mendapatkan terapi dobutamin $5 \mathrm{mcg} /$ $\mathrm{kgBB} / \mathrm{menit}$, norephinephrine $0.1 \mathrm{mcg} / \mathrm{kgBB} / \mathrm{menit}$. Brain (B3): kesadaran pasien dibawah pengaruh obat midazolam $1 \mathrm{mg} /$ jam. Bladder (B4): pasien terpasang foley catheter dengan produksi urine 50 - 100 cc per jam. Bowel (B5): berat badan pasien adalah $55 \mathrm{~kg}$ dengan tinggi badan $160 \mathrm{~cm}$ (indeks massa tubuh 21,5), pasien terpasang naso gastric tube, dengan diet berupa diet tinggi kalori tinggi protein (TKTP) cair 6x200 cc (total $2.400 \mathrm{Kkal} / 24$ jam). Bone (B6): pada ekstremitas bawah kanan (femur) terdapat luka post disartikulasi panggul berukuran diameter $\pm 15 \mathrm{~cm}$, terdapat slough dan pus yang keluar dari sela jahitan luka.

Pengkajian sepsis pada pasien sakit kritis dilakukan dengan menggunakan Sequential Organ Failure Assessment Score (SOFA). SOFA menggunakan 6 sistem organ sebagai indikator penilaian dengan skor 0 (tidak ada disfungsi) sampai 4 (terjadi disfungsi yang parah). Indikator tersebut menilai fungsi respirasi (Pa02/Fi02), koagulasi (kadar platelet), liver (kadar bilirubin), sistem syaraf pusat (pemeriksaan Glasgow Coma Score (GCS)), kardiovaskular (kondisi hipotensi), dan fungsi renal (kadar kreatinin) (Dellinger et al., 2013). Berikut merupakan perhitungan skor SOFA pada pasien.

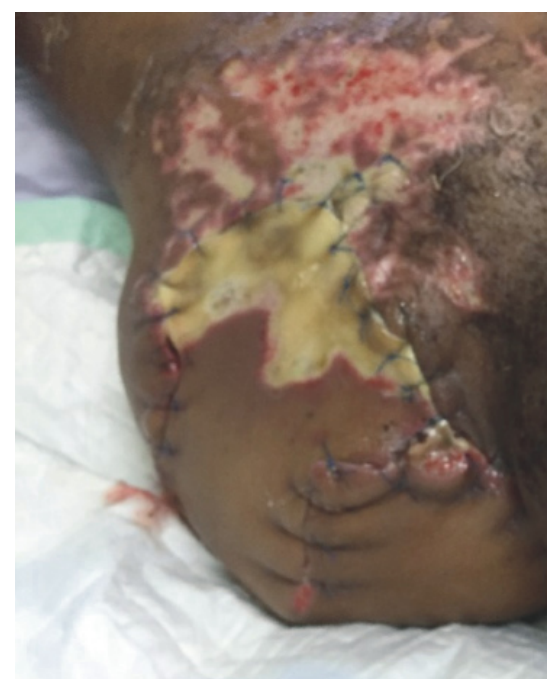

\section{Gambar 2. Kondisi luka post disartikulasi panggul kanan}

Tabel 1. Perhitungan sequential organ failure assessment (SOFA) pada pasien

\begin{tabular}{llc}
\hline \multicolumn{1}{c}{ Indikator } & \multicolumn{1}{c}{ Hasil } & Nilai \\
\hline $\begin{array}{l}\text { PaO2/ Fio2 } \\
(\mathrm{mmHg})\end{array}$ & 61,5 & 4 \\
\hline Platelets $\left(\mathrm{x} 10^{3} \mu \mathrm{l}\right)$ & 103 & 1 \\
\hline $\begin{array}{l}\text { Glasgow coma } \\
\text { score }\end{array}$ & $6-9$ & 3 \\
\hline Bilirubin $(\mathrm{mg} / \mathrm{dl})$ & 0,88 & 0 \\
\hline Hipotensi & $\begin{array}{l}\text { Menggunakan } \\
\text { norepinephrine }=0,1 \\
\text { mcg/kgBB } / \mathrm{mnt}\end{array}$ & 3 \\
\hline Kreatinin $(\mathrm{mg} / \mathrm{dL})$ & 0,76 & 0 \\
\hline Skor total & & 11 \\
\hline
\end{tabular}

Selain pengkajian dengan SOFA, dilakukan pemeriksaan laboratorium yang menunjang pengkajian sepsis pada pasien yaitu: kadar leukosit 13.67103 $\mu \mathrm{L}$, dan procalcitonin $16,37 \mathrm{ng} / \mathrm{mL}$. Pemeriksaan foto thorax menunjukkan adanya pneumonia, sedangkan pemeriksaan ultra sonography (USG) abdomen menunjukkan adanya lesi hyperechoic pada lobus kiri hepar dan spleen, dengan kesimpulan suspek hematoma.

Pasien mendapat terapi obat-obatan levofloxacin $1 \times 750 \mathrm{mg}$, omeprazole 1 x $40 \mathrm{mg}$, metoclopramid $3 \times 10 \mathrm{mg}$, paracetamol $3 \times 1 \mathrm{gr}$, dobutamin $5 \mathrm{mcg} /$ $\mathrm{kgBB} /$ menit, norepinephrine $0.1 \mathrm{mcg} / \mathrm{kgBB} / \mathrm{menit}$, midazolam $1 \mathrm{mg} / \mathrm{jam}$, Terapi cairan pada pasien adalah $\mathrm{NaCl}$ 0,9\% $500 \mathrm{cc} / 24$ jam. 


\section{PEMBAHASAN}

Pada kasus diatas, seorang pasien mengalami cedera ledakan yang mengakibatkan luka bakar derajat 3 pada area abdomen dan paha kanan, serta trauma femur kanan. Pasien mengalami tindakan pembedahan berupa disartikulasi panggul kanan dan debridement luka pada abdomen. Pasca pembedahan, klien dirawat di ruang rawat intensif.

Hasil pengkajian terhadap kondisi sepsis menunjukkan pasien memiliki skor SOFA 11. Skor SOFA $\geq 2$ mengindikasikan pasien mengalami sepsis. Pasien dengan skor SOFA $\geq 2$ berhubungan dengan kenaikan angka kematian di rumah sakit (in hospital mortality) > 10\% (Singer et al., 2016). Kondisi sepsis pada pasien didukung oleh hasil pemeriksaan laboratorium yaitu kadar leukosit $13.67103 \mu \mathrm{L}$, dan procalcitonin $16,37 \mathrm{ng} / \mathrm{mL}$. Peningkatan kadar leukosit mengindikasikan pasien mengalami infeksi, sedangkan kadar procalcitonin $>2 \mathrm{ng} / \mathrm{mL}$ menunjukkan resiko tinggi untuk terjadinya sepsis berat atau resiko pasien mengalami syok septik (Oro, Gauthreaux, Lamoureux, \& Scott, 2019).

Sepsis merupakan hasil interaksi kompleks detection molecules, signaling molecules, dan mediator inflamasidan koagulasi sebagai respon terhadapinfeksi. Beberapa sumber infeksi yang mungkin merupakan pencetus sepsis pada pasien adalah pneumonia, dan infeksi luka post operasi disartikulasi panggul kanan.

Pada saat pasien mengalami infeksi, respon awal tubuh adalah mobilisasi sel-sel inflamasi, terutama netrofil dan makrofag ke lokasi infeksi. Kemudian selsel tersebut melepaskan molekul sirkulasi, termasuk sitokin, yang memicu pengeluaran mediator inflamasi lainnya (Marx, Hockberger, \& Walls, 2014). Mediator proinflamasi yaitu sitokin (TNF- $\alpha$, IL-1, IL-6), kemokin (IL-8), prostaglandin dan histamin. Mediator-tersebut bekerja pada sel endotel pembuluh darah sehingga menyebabkan respon inflamasi yaitu vasodilatasi, peningkatan permeabilitas pembuluh darah dan perekrutan neutrofil ke jaringan (Oematan, Manoppo, \& Runtunuwu, 2009). Apabila respon inflamasi pasien adekuat, maka infeksi dapat terkontrol dan teratasi. Namun apabila tubuh tidak dapat mengatur pengeluaran mediator tersebut dengan baik, maka akan terjadi sepsis. Sepsis terjadi ketika agen infeksi mengeluarkan toksin secara terus-menerus. Akibatnya, terjadi respon inflamasi yang menetap melalui aktivasi mediator inflamasi secara terus menerus, hipoksia seluler, kerusakan jaringan, syok, kegagalan organ, dan berpotensi mengakibatkan kematian (Bennett et al., 2015).

Penatalaksanaan pasien sepsis yang dikeluarkan oleh the Surviving Sepsis Campaign (SSC) pada tahun 2018 yaitu Hour-1 Surviving Sepsis Campaign Bundle of Care meliputi: pengukuran kadar laktat (lakukan pengukuran kembali apabila kadar laktat >2 mmol/L), kultur darah sebelum pemberian antibiotik, pemberian antibiotik spektrum luas, segera beri terapi cairan kristaloid $30 \mathrm{ml} / \mathrm{kgBB}$ apabila pasien mengalami hipotensi atau memiliki kadar laktat $\geq 4 \mathrm{mmol} / \mathrm{L}$, pemberian vasopressor apabila pasien mengalami hipotensi selama atau setelah pemberian resusitasi cairan (untuk mempertahankan mean arterial pressure (MAP) $\geq 65$ mmHg (Gyawali, Ramakrishna, \& Dhamoon, 2019; Levy, Evans, \& Rhodes, 2018). Sepsis dapat menyebabkan kondisi hipoperfusi sehingga terjadi disfungsi organ. Tindakan tersebut bertujuan untuk mengidentifikasi dan mempertahankan perfusi jaringan yang adekuat, serta manajemen infeksi pada pasien dengan sepsis (Gyawali et al., 2019).

Pengkajian keperawatan pada pasien dengan sepsis tersebut memunculkan beberapa prioritas masalah keperawatan yaitu ketidakefektifan bersihan jalan napas, hambatan ventilasi spontan, risiko syok, dan kerusakan integritas jaringan (NANDA-I, 2018).

Ketidakefektifan bersihan jalan napas: pasien tersebut mengalami pneumonia akibat pemakaian ventilator mekanik (ventilator associated pneumonia (VAP)) yang ditandai dengan respon batuk, produksi sputum purulen (konsistensi kental, berwarna kuning pekat), dan terdengar ronkhi pada lobus paru kiri dan kanan atas. Pasien menggunakan ETT sehingga perlu tindakan suction untuk mengeluarkan sputum. Kriteria hasil berupa nursing outcome classification (NOC) yang dipilih adalah status pernapasan: kepatenan jalan napas, meliputi frekuensi pernapasan, irama pernapasan, suara napas tambahan (ronkhi), penggunaan otot bantu napas, batuk, dan akumulasi sputum (Moorhead, Johnson, Maas, \& Swanson, 2013). Rencana intervensi berupa nursing intervention classification (NIC) yang dipilih adalah suctioning jalan napas (Bulechek, Butcher, Dochterman, \& Wagner, 2013). Perawat melakukan suction pada pasien dengan prinsip steril, dan memperhatikan respon 
pasien berupa status oksigenasi (saturasi oksigen), serta status hemodinamik (mean arterial pressure (MAP) dan irama jantung) sebelum, selama, dan setelah tindakan suction. Teknik suction yang dipilih adalah closed suction karena pasien menggunakan ventilasi mekanik. Penggunaan teknik closed suction berdampak lebih baik dalam mempertahankan volume paru pada pasien dengan ventilasi mekanik, karena tidak perlu melepaskan alat ventilator mekanik saat tindakan suction (Liu, Jin, Ma, Qu, \& Liu, 2015).

Hambatan ventilasi spontan: pasien mengalami kondisi gagal napas yaitu tidak mampu bernapas spontan sehingga harus dibantu oleh ventilasi mekanik. Penggunaan ventilasi mekanik ini sesuai dengan penatalaksanaan yang direkomendasikan oleh Surviving Sepsis Campaign pada pasien sepsis yang mengalami acute respiratory distress syndrome (ARDS) (Lester, Hartjes, \& Bennett, 2018). Mode ventilasi mekanik yang digunakan adalah: PC - SIMV, PEEP: 6, Frekuensi: 22 x/menit, TV(i) : 263 ml, MV (i): 7.6 lpm, P Support: 15 mmH20, P inspirasi / P control: 24 mmH2O, Triger $2 \mathrm{lpm}$, FiO2: 100\%. NOC yang dipilih adalah respon ventilasi mekanik: dewasa, meliputi frekuensi pernapasan, irama pernapasan, volume tidal, FiO2, $\mathrm{PaO} 2, \mathrm{PaCO} 2$, saturasi oksigen, $\mathrm{pH}$ arteri, dan pemeriksaan penunjang berupa hasil chest $\mathrm{x}$-ray. NIC yang dipilih adalah manajemen ventilasi mekanik: invasif. Perawat memastikan pasien berespon positif terhadap setting ventilator mekanik. Perkembangan respon pasien terhadap terapi dipantau melalui status respirasi, hasil pemeriksaan analisis gas darah, dan chest $\mathrm{x}$-ray. Pada pasien tersebut telah terjadi pneumonia akibat penggunaan ventilator mekanik(VAP). Salah satu penatalaksanaan pasien dengan VAP yaitu oral hygiene menggunakan clorhexidine (Gnatta, Silveira, Lacerda, \& Padoveze, 2013; Zuckerman, 2016). Studi Keenan (2017) pada 2.451 pasien menunjukkan bahwa oral hygiene dengan clorhexidine menurunkan resiko VAP dari 25\% menjadi 19\% (Keenan \& Ferraiolo, 2017).

Risiko syok: tekanan darah pasien adalah 115125/57-77 mmHg, nadi 120-135 x/menit dengan bantuan obat dobutamin $5 \mathrm{mcg} / \mathrm{kgBB} / \mathrm{menit}$ dan norephinephrine $0.1 \mathrm{mcg} / \mathrm{kgBB} /$ menit. Pada pasien dengan sepsis, terjadi perubahan pada tubuh. Vasodilatasi sistemik dapat menyebabkan hipotensi, shunting dan berkurangnya penghantaran oksigen jaringan. Aktivasi endotel dan apoptosis mengakibatkan hilangnya integritas pembuluh darah, eksudat proteinase dan edema. Disseminated intravascular coagulation (DIC) mengakibatkan mikrotrombosis pembuluh darah kecil, deplesi faktor pembekuan dan koagulopati. Efek kumulatif dari perubahan tersebut mengakibatkan pasien dapat mengalami syok septik (Oematan et al., 2009). NOC yang dipilih adalah status kardiopulmoner meliputi parameter tekanan darah, nadi perifer, irama jantung, frekuensi dan irama pernapasan, produksi urine, saturasi oksigen, dan tingkat kesadaran. NIC yang dipilih adalah pencegahan syok, dan manajemen syok. Perawat mengobservasi tanda dan gejala syok, perfusi jaringan, serta status hemodinamik pasien. Perawat berkolaborasi dalam pemberian obat-obatan seperti vasopressor, dan antibiotik, dan pemberian terapi cairan bagi pasien.

Kerusakan integritas jaringan: pada abdomen klien terdapat luka bakar derajat III seluas 18\% (post debridement), serta terdapat luka post operasi disartikulasi panggul kanan berukuran diameter \pm 15 cm yang terinfeksi, ditandai dengan adanya pus yang keluar dari sela jahitan luka. Luka tersebut merupakan salah satu sumber infeksi penyebab sepsis pada pasien. Perawat perlu melakukan prosedur perawatan luka bakar dan luka post operasi dengan teknik modern wound dressing yang menitik beratkan pada prinsip moist sehingga jaringan luka mengalami kesempatan untuk berproliferasi melakukan siklus perbaikan sel dengan baik (Fatmadona \& Oktarina, 2016). NOC yang dipilih adalah wound healing: primary intention untuk luka post operasi disartikulasi panggul kanan meliputi eritema, drainase, edema, dan epitelisasi/penutupan luka, dan wound healing: secondary intention untuk luka bakar di abdomen meliputi eritema, drainase, inflamasi, edema, nekrosis, sloughing, dan bau. NIC yang dipilih adalah wound care untuk luka post operasi disartikulasi panggul kanan, dan wound care: burns untuk luka bakar di abdomen. Perawat melakukan tindakan merawat luka berupa pengkajian luka, mengobservasi tanda-tanda infeksi, membersihkan luka, mengangkat slough dan jaringan nekrosis, mengeluarkan pus, mengoleskan obat topikal, serta memberikan dressing yang sesuai untuk jenis luka. Perawat melakukan pengambilan spesimen luka untuk kultur sehingga dapat ditentukan terapi antibiotik yang tepat untuk manajemen infeksi luka, serta memastikan pasien mendapatkan asupan cairan dan nutrisi yang 
adekuat untuk mendukung proses penyembuhan luka.

Evaluasi tindakan keperawatan pada minggu pertama menunjukkan bersihan jalan napas meningkat (akumulasi sputum berkurang), pasien masih menggunakan ventilasi mekanik dengan status respirasi stabil, pasien masih menggunakan vasopressor namun status hemodinamik stabil, dan kondisi luka bersih. Perawat melanjutkan intervensi keperawatan pada pasien sampai pasien mengalami perbaikan kondisi, dan masalah teratasi.

\section{KESIMPULAN}

Seorang pasien mengalami cedera ledakan yang menyebabkan luka bakar pada area abdomen, serta

\section{DAFTAR PUSTAKA}

Bennett, J. E., Dolin, R., \& Blaser, M. J. (2015). Mandell, Douglas, and Bennett's Principles and Practice of Infectious Diseases (8th ed.). Philadelphia: Saunders.

BPKN (2010). [Pelabelan Tabung Gas Rumah Tangga Gas $3 \mathrm{~kg}$ dan $12 \mathrm{~kg}$ ].

Bulechek, G. M., Butcher, H. K., Dochterman, J. M., \& Wagner, C. (2013). Nursing Interventions Classification (NIC) (6th ed.). Missouri: Elsevier.

Camm, C. F., Hayward, G., Elias, T. C. N., Bowen, o. S. T., Hassanzadeh, R., Fanshawe, T., . . . Lasserson, D. S. (2018). Sepsis recognition tools in acute ambulatory care: associations with process of care and clinical outcomes in a service evaluation of an emergency multidisciplinary unit in Oxfordshire. BMJ Open, 8, e020497.

Fatmadona, R., \& Oktarina, E. (2016). Aplikasi modern wound care pada perawatan luka infeksi di RS Pemerintah Kota Padang. Ners Jurnal Keperawatan, 12(2), 159-165.

Finkelsztein, E. J., Jones, D. S., Ma, K. C., Pabón, M. A., Delgado, T., Nakahira, K., ... Siempos, I. I. (2017). Comparison of qSOFA and SIRS for predicting adverse outcomes of patients with suspicion of sepsis outside the intensive care unit. Critical Care, 21(73), 1-10.

Gnatta, J. R., Silveira, I. R. d., Lacerda, R. A., \& Padoveze, M. C. (2013). Evidence on the best chlorhexidine concentration to perform oral hygiene: metaanalysis. 0 Mundo da Saude, 37(4), 464-471. trauma femur. Pasien mengalami tindakan pembedahan berupa disartikulasi panggul kanan dan debridement luka pada area abdomen. Pasien mengalami gagal napas dan memerlukan pemantauan hemodinamik sehingga dirawat di ruang rawat intensif. Pasien mengalami kondisi sepsis yang dengan pencetus pneumonia dan infeksi pada luka. Prioritas masalah keperawatan pada pasien yaitu ketidakefektifan bersihan jalan napas, hambatan ventilasi spontan, risiko syok, dan kerusakan integritas jaringan. Perawat melakukan asuhan keperawatan untuk mempertahankan kepatenan jalan nafas, memberikan ventilasi yang adekuat, mempertahankan kestabilan hemodinamik, serta mengoptimalkan proses penyembuhan luka pada pasien.

Gyawali, B., Ramakrishna, K., \& Dhamoon, A. S. (2019). Sepsis: The evolution in definition, pathophysiology, and management. SAGE Open Medicine, 7, 1-13.

Jorolemon, M. R., \& Krywko, D. M. (2019). Blast Injuries. https://www.ncbi.nlm.nih.gov/books/ NBK430914/

Keenan, A.-V., \& Ferraiolo, D. M. (2017). Oral care with chlorhexidine seems effective for reducing the incidence of ventilator-associated pneumonia. Evidence-Based Dentistry, 18, 113-114.

Lester, D., Hartjes, T., \& Bennett, A. (2018). A Review of the revised sepsis care bundles: The rationale behind the new definitions, screening tools, and treatment guidelines. AJN, 118(8), 40-49.

Levy, i. M., Evans, L. E., \& Rhodes, A. (2018). The surviving sepsis campaign bundle: 2018 update. Critical Care Medicine, 46(6), 997-1000.

Liu, X.-W., Jin, Y., Ma, T., Qu, B., \& Liu, Z. (2015). Differential effects of endotracheal suctioning on gas exchanges in patients with acute respiratory failure under pressure-controlled and volumecontrolled ventilation. Biomed Res Int, 2015, 941081. doi: 10.1155/2015/941081

Marx, J. A., Hockberger, R. S., \& Walls, R. M. (2014). Rosen's Emergency Medicine (8th ed.). Philadelphia: Saunders.

Moorhead, S., Johnson, M., Maas, M. L., \& Swanson, E. (2013). Nursing Outcomes Classification (NOC) (5th ed.). Missouri: Elsevier. 
NANDA-I. (2018). Diagnosis Keperawatan Definisi dan Klasifikasinya 2018-2020 (11 ed.). Jakarta: EGC.

Oematan, Y., Manoppo, J. I. C., \& Runtunuwu, A. L. (2009). Peran inflamasi dalam patofisiologi sepsis dan syok septik pada anak. Jurnal Biomedik, 1(3), 166-173.

Oro, N. D., Gauthreaux, M. E., Lamoureux, J., \& Scott, J. (2019). The use of procalcitonin as a sepsis marker in a community hospital. J Appl Lab Med, $3(4), 545-552$.

Samra, T., Pawar, M., \& Kaur, J. (2014). Challenges in management of blast injuries in Intensive Care
Unit: Case series and review. Indian J Crit Care Med, 18(12), 814-818.

Singer, M., Deutschman, C. S., Seymour, C. W., ShankarHari, M., Annane, D., Bauer, M., . . Chiche, J.-D. (2016). The third international consensus definitions for sepsis and septic shock (sepsis-3). JAMA, 315(8), 801-810.

Syafii,A.(2017).Upaya pencegahandanpenanggulangan tindak pidana terorisme di Indonesia. Maleo Law Journal, 1(2), 168-186.

Zuckerman, L. M. (2016). Oral chlorhexidine use to prevent ventilator-associated pneumonia in adults. Dimens Crit Care Nurs, 35(1), 25-36. 